\title{
Noam Chomsky and the Public Intellectual in Dark Times
}

\author{
Henry A. Giroux
}

In a market-driven system in which economic and political decisions are removed from social costs, the flight of critical thought and social responsibility is accentuated by what Zygmunt Bauman calls "ethical tranquillization.”[1] One result is a form of depoliticization that works its way through the social order, removing social relations from the configurations of power that shape them, substituting what Wendy Brown calls "emotional and personal vocabularies for political ones in formulating solutions to political problems.' [2] Consequently, it becomes difficult for young people too often bereft of a critical education to translate private troubles into public concerns. As private interests trump the public good, public spaces are corroded and short-term personal advantage replaces any larger notion of civic engagement and social responsibility. Under the restricted rationality of the market, pubic spheres and educational realms necessary for students to imagine alternative futures and horizons of possibility begin to disappear as do the public intellectuals who embrace "the idea of a life dedicated to values that cannot possibly be realized by a commercial civilization [who rejects the idea that] loyalty, not truth, provides the social condition by which the intellectual discovers his new environment."[3]

In a dystopian world shaped by twenty-five years of neoliberal savagery with its incessant assault on public values, the common good, and social responsibility, it has become difficult to remember what a purposeful and substantive democracy looks like or for that matter what the idea of democracy might suggest. Democracy as both an ideal and working practice is under assault just as a number of anti-democratic educational, market, military, and religious fundamentalisms are gaining ascendency in American society. Increasingly, it becomes more difficult to inhabit those public spheres where politics thrives - where thinking, speaking, and acting subjects engage and critically address the major forces and problems bearing down on their lives. In this new moment in history, the symbiotic relationship among cultural institutions, political power, and everyday life has taken on a new register. The educative nature of politics has now become one of the most important elements shaping how people think, desire, act, and behave. The question of how society should imagine itself or what its future might hold has become more difficult given the eradication of social formations that place an emphasis on cooperation, trust, honesty, and compassion. As a robust democratic sociality is lost to the imperatives of commerce and a harsh winner-take-all Social Darwinism, there has emerged what Richard Sennett calls a new character type: "an uncooperative self, illdisposed for dealing with complexity and difference." [4] This character type is increasingly embodied in a new type of intellectual that has become entirely beholden to corporate power and whose ideas, values, and interaction with the American people is bereft of any sense of equality, justice, or ethical considerations. The American people are now beholden pedagogically to what might be called the anti-public intellectual.

Under such circumstances, to cite C. W. Mills, we are witnessing the breakdown of democracy, the infantilization of thought, the disappearance of critical intellectuals, and "the collapse of those public spheres which offer a sense of critical agency and social imagination." [5] Mill's prescient comments amplify what has become a tragic reality. Missing from neoliberal market societies are those public intellectuals who connect scholarship to larger public issues, provide a model of moral witnessing for young people, and embody the struggle to deepen and energize the civic imagination. Neoliberalism has produced and supported over the last 40 years a host of foundations, institutes, and cultural apparatuses in which to produce a new kind of public intellectual, that is, an anti-public intellectual who rails 
against the social state, social wage, unions, and any other public sphere that offers the public a discourse and mode of subjectivity that operates in the public interest, in support of what might be called the democratic commons. From Bill Gates to Bill Kristol, the American public is inundated with arguments that privilege the market over social needs, individualize the social, and make exchange value the only value that counts. These anti-public intellectuals now dominate the mainstream media and have been waging a war against higher education, public transportation, social provisions such as food stamps and social security. As Noam Chomsky points out:

There are major efforts being made to dismantle Social Security, the public schools, the post office-anything that benefits the population has to be dismantled. Efforts against the U.S. Postal Service are particularly surreal. I'm old enough to remember the Great Depression, a time when the country was quite poor but there were still postal deliveries. Today, post offices, Social Security, and public schools all have to be dismantled because they are seen as being based on a principle that is regarded as extremely dangerous.[6]

These subsidized anti-public intellectuals are not driven by the search for truth but by loyalty to corporate power, all the while producing and legitimating policy that is as authoritarian as it is cruel and stupid, whether it is curbing the reproductive rights of women and preventing environmental reforms or the teaching of creationism in the schools. For example, in the last few decades, we have seen market mentalities attempt to strip education of its public values, critical content, and civic responsibilities as part of its broader goal of creating new subjects wedded to consumerism, risk-free relationships, and the disappearance of the social state in the name of individual, expanded choice. Tied largely to instrumental ideologies and measurable paradigms, many institutions of higher education are now committed almost exclusively to economic goals, such as preparing students for the workforce-all done as part of an appeal to rationality, one that eschews matters of inequality, power, and the ethical grammars of suffering.[7]

In what follows, I want to address the work of Noam Chomsky and his role as a public intellectual. I argue that Chomsky's role intellectually, educationally, and politically is more relevant now than ever given the need for a display of civic courage, theoretical rigor, and a willingness to translate private troubles into public concerns. Moreover, he provides a model for young people and others to understand the importance of using ideas and knowledge to intervene politically in civic, political, and cultural life in order to make clear that democracy has to produce informed and critical agents who believe that democracy has to be struggled over, if it is going to survive.

Noam Chomsky is a world renowned academic best known not only for his pioneering work in linguistics but also for his ongoing work as a public intellectual in which he has addressed a number of important social issues that include and often connect oppressive foreign and domestic policies--a fact well illustrated in his numerous path breaking books.[8] If fact, Chomsky's oeuvre includes too many exceptionally important books, making it all the more difficult to single out any one of them from his extraordinary and voluminous archive of work. Moreover, as political interventions, his many books often reflect both a decisive contribution and an engagement with a number of issues that have and continue to dominate a series of specific historical moments over the course of fifty years. His political interventions have been historically specific while continually building on the power relations he has engaged critically. For instance, his initial ideas about the responsibility of intellectuals cannot be separated from his early criticisms of the Vietnam War and the complicity of intellectuals in brokering and legitimating that horrendous act of military intervention.[9] Hence, it becomes trying to compare his 1988 book, Manufacturing Consent, coauthored with Edward S. Herman with his 2002 bestseller, 9/11. Yet, what all of these texts share is a luminous theoretical, political, and forensic analysis of the functioning of the current global power structure, new and old modes of oppressive authority, and the ways in which neoliberal economic and social policies have produced more savage forms of global domination and corporate sovereignty.

His many recent books, articles, and interviews have addressed how the new reign of neoliberal capital is normalized not only through military and economic relations but also through the production of new forms of subjectivity organized around the enslavement of debt, the security-surveillance state, the corporatization of higher education, the rise of finance capital, and the powerful corporate controlled cultural apparatuses that give new power and force to the simultaneously educative and repressive nature of politics. Chomsky does not subscribe to a onedimensional notion of power that one often finds among many on the left who view power as driven exclusively by economic forces. He keenly understands that power is multifaceted, operating through a number of material and symbolic registers, and he is particularly astute in pointing out that power also has a pedagogical function and must include an historical understanding of the public relations industry, existing and emerging cultural apparatuses, and that central to matters of power, agency, and the radical imagination are modes of persuasion, the shaping of identities, and the molding of desire. 
Rooted in the fundamentals of anarcho-syndicalism and democratic socialism, he has incessantly exposed the gap between the reality and the promise of a radical democracy, particularly in the United States, though he has provided detailed analysis of how the deformation of democracy works in a number of countries that hide their diverse modes of oppression behind the false claims of democratization. Chomsky has attempted to refigure both the promise of democracy and develop new ways to theorize agency and the social imagination outside of the neoliberal focus on individualization, privatization, and the assumption that the only value that matters is exchange value. Unlike many intellectuals who are trapped in the discourse of academic silos and a sclerotic professionalism, he writes and speaks from the perspective of what might be called contingent totalities. In so doing, he connects a wide variety of issues as part of a larger understanding of the diverse and specific economic, social, and political forces that shape people's lives in particular historical conjunctures. He is one of the few North American theorists who embrace modes of solidarity and collective struggle less as an afterthought than as central to what it means to connect the civic, social, and ethical as the foundation for global resistance movements. Implicit to his role as a public intellectual is the question of what a real democracy should look like, how are its ideals and practices subverted, and what are the forces necessary to bring it into being?

As someone who has been writing about youth, neoliberalism, disposability, the rise of the punishing state, the centrality of education to politics, and the notion that politics is about not only the struggle over power and economics but also the struggle over particular modes of culture, subjectivity and agency, his work has been invaluable to me and many others. While it is often pointed out that he is one of the most influential left critics of American foreign policy, what is unique about his ongoing analyses is that his work is layered, complex, often connecting issues far removed from more narrow analyses of foreign policy. For Chomsky, crises are viewed as overlapping, merging into each other in ways that often go unrecognized. Accordingly, in this paradigm, the war on education cannot be understood if removed from the war on the social state, just as the rise of the punishing state cannot be removed from harsh and punitive survival-of-the-fittest ethic that now characterizes a mode of savage neoliberalism in the United States in which the ruling classes no longer believe in political concessions because their power is global while politics is local and colonized by neoliberal geopolitical power relations. In fact, Chomsky often brings together in his work issues such as terrorism, corporate power, United States exceptionalism, and other major concerns so as to provide maps that enable his readers to refigure the landscape of political, cultural, and social life in ways that offer up new connections and the possibility for fresh modes of theorizing potential resistance.

He has also written about the possibility of political and economic alternatives, offering a fresh language for a collective sense of agency and resistance, a new understanding of the commons, and a rewriting of the relations between the political and the up-to-date institutions of culture, finance, and capital. And, yet, he does not provide recipes but speaks to emerging modes of imaginative resistance always set within the boundaries of specific historical conjunctures. His work is especially important in understanding the necessity of public intellectuals in a time of utter tyranny, cruelty, financial savagery, and a mode of soft authoritarianism. His work should be required reading for all academics, students, and the wider public. Given that he is one of the most cited intellectuals in the world suggests strongly that his audience is general, diverse, and widespread, inhabiting many different sites, public spheres, and locations.

Chomsky is fiercely critical of fashionable conservative and liberal attempts to divorce intellectual activities from politics and is quite frank in his notion that education both in and out of institutional schooling should be involved in the practice of freedom and not just the pursuit of truth. He has strongly argued that educators, artists, journalists, and other intellectuals have a responsibility to provide students and the wider public with the knowledge and skills they need to be able to learn how to think rigorously, be self-reflective, and to develop the capacity to govern rather than be governed. But for Chomsky it is not enough to learn how to think critically. Engaged intellectuals must also develop an ethical imagination and sense of social responsibility necessary to make power accountable and to deepen the possibilities for everyone to live a life infused with freedom, liberty, decency, dignity, and justice. On higher education, Chomsky has been arguing since the sixties that in a healthy society universities must press the claims for economic and social justice and that any education that matters must not merely be critical but also subversive. Chomsky has been unflinching in his belief that education should disturb the peace, and engage in the production of knowledge that is critical of the status quo, particularly in a time of legitimized violence. He has also been clear, as were his political counterparts the late Pierre Bourdieu and Edward Said, in asserting that intellectuals had to make their voices accessible to a wider public and be heard in all of those spheres of public life in which there is an ongoing struggle over knowledge, values, power, identity, agency, and the social imagination.

Capitalism may have found an honored place for many of its anti-public intellectuals, but it certainly has no room 
for the likes of Chomsky. Conservatives and liberals along with an army of unyielding neoliberal advocates have virtually refused to include him in the many discussions and publications on social issues that work their way into the various registers of the dominant media. In many ways, Chomsky's role as an intellectual and activist is a prototype of what may be called an American radical tradition and yet appears out of place. Chomsky appears to be an exile in his own country by virtue of his political interventions, the shock of his acts of translation, and his displays of fierce courage. As Zygmunt Bauman has argued the "distinguishing mark" of the writer as exile "is the refusal to be integrated-the determination to ...conjure up a place of one's own, different from the place which those around are settled, a place unlike the places left behind and unlike the place of arrival.'[10] This is not to suggest that he would make a claim to be in exile the sense claimed by many intellectuals, though he might agree with the late Edward Said who was interested in what he called "travelling theory" in the sense of "being errant, provisional, intellectually on the hoof, [as one of] several ways in which he remained true to the exiled people to whom he lent his voice."[11] Exile in this sense suggest that as a "traveler" Chomsky is not interested staking out academic territory and consequently has no disciplinary sphere to protect.

Chomsky is interested in connecting intellectual competencies and critical independence with matters of social responsibility. His political and theoretical purview is capacious. Unlike, many academics today who are caught in the cult of specialization and forms of disciplinary terror-forever excoriating those intellectuals who attempt to breach the steadfast rules of the discipline, Chomsky is committed to an intellectual vocation that questions authority, breaks down the dominant appeal to commonsense, and exercises a "heighted sensitivity to oppression and injustice."[12]

Terry Eagleton offers a definition of how academics are different from public intellectuals that I think is useful in understanding Chomsky's work. He writes:

Intellectuals are not only different from academics, but almost the opposite of them. Academics usually plough through a narrow disciplinary patch, whereas intellectuals ...roam ambitiously from one discipline to another. Academics are interested in ideas, whereas intellectuals seek to bring ideas to an entire culture....Anger and academia do not usually go together, except perhaps when it comes to low pay, whereas anger and intellectuals do. Above all, academics are conscious of the difficult, untidy, nuanced nature of things, while intellectuals take sides. ... in all the most pressing political conflicts which confront us, someone is going to have to win and someone to lose. It is this, not a deaf ear for nuance and subtlety, which marks them out from the liberal.[13]

While this description does not perfectly fit Chomsky, I think it is fair to say that his main role as a public intellectual is to lift ideas into the public realm in the hopes of exposing how power relations works for and against justice, how they are legitimated, and what can be done to challenge them. Many have commented on his staid delivery when he gives talks, but what they often fail to recognize is the sense of political and moral outrage that animates his diverse roles as a public intellectual. At the same time Chomsky is certainly an academic in terms of his rigorous intellectual work, but the point is that he is more than that. In the end, Chomsky's dialectical move between theory and practice, rigor and accessibility, critique and action offers up less a reason to praise him than to offer a noble vision of what we should all strive for.

As an engaged academic, Chomsky publically argues against regimes of domination organized for the production of violence and social and civil death. His ghostly presence offers up the possibility of dangerous memories, alternative ways of imagining society and the future, and the necessity of public criticism as one important element of individual and collective resistance. And, yet, Chomsky's role as a public intellectual, given the huge audiences that he attracts when he lectures as well as his large reading public, suggests that there is no politics that matters without a sense of connecting meaningfully with others. Politics becomes emancipatory when it takes seriously that, as Stuart Hall has noted, "people have to invest something of themselves, something that they recognize is of them or speaks to their condition, and without that moment of recognition...p politics will go on, but you won't have a political movement without that moment of identification."[14] Chomsky has clearly connected with a need among the public for those intellectuals willing to make power visible, to offer an alternative understanding of the world, and to point to the hopes of a future that does not imitate the scurrilous present.

Chomsky has been relentless in reminding his audience that power takes many forms and that the production of ignorance is not merely about the crisis of test scores or a natural state of affairs-an idiotic argument if there ever was one-but about how ignorance is often produced in the service of power. According to Chomsky, ignorance is a pedagogical formation that is used to stifle critical thinking and promotes a form of anti-politics, which undermines matters of judgment and thoughtfulness which are central to politics. At the same time, neoliberalism's public pedagogy of ignorance is a crucial player in not just producing consent but also in squelching dissent. For Chomsky, 
ignorance is a political weapon that benefits the powerful, not a general condition rooted in some inexplicable human condition. One of his most insistent themes focuses on how state power functions in various forms as a mode of terrorism reigning violence, misery, and hardship often as a function of class warfare and American global imperialism and how people are often complicitous with such acts of barbarism. Chomsky has been particularly insightful in arguing that the state thrives on keeping the American public ignorant so that it can render its illegal practices invisible and protect the "security of state power from exposure."[15] He writes:

There is, of course, a sense in which security is threatened by public awareness .... The basic insight was expressed well by the Harvard political scientist Samuel P. Huntington: 'The architects of power in the United States must create a force that can be felt but not seen. Power remains strong when it remains in the dark; exposed to the sunlight it begins to evaporate.'[16]

At the same time, Chomsky is an ardent defender of the poor, those populations considered disposable, the excluded, and those marginalized by class, race, gender, and other ideologies and structural relations considered threatening to tyrants both at home and abroad. There is no privileged, singularly oppressed group in Chomsky's work. He is capacious in making visible and interrogating oppression in its multiple forms, regardless of where it exists. Yet, while Chomsky has his critics ranging from notables such as Sheldon Wolin and Martha Nussbaum to a host of less informed interlocutors, he rarely shies away from a reasoned debate, often elevating such exchanges to a new level of understanding and in some cases embarrassment for his opponents.[17] Some of his more illustrious and infamous debaters have included Michel Foucault, William Buckley, Jr., John Silber, Christopher Hitchens, and Alan Dershowitz. At the same time, he has refused, in spite of the occasional and most hateful and insipid of attacks, to mimic such tactics in responding to his less civil denigrators.[18] Some of Chomsky's detractors have accused him of being too strident, not theoretical enough, or more recently of not understanding the true nature of ideology. These criticisms seem empty and baseless to me and appear irrelevant considering the impact Chomsky's work has had on a younger generation, including many in the Occupy Movement, in calling into question the reckless mechanizations and dynamics of politics, power, and policies of the United States government and other authoritarian regimes.

It is important to note that I am not suggesting that Chomsky is somehow an iconic figure who inhabits an intellectual version of celebrity culture. On the contrary, he deplores such a role and is an enormously humble and self-effacing human being. What I am contending, however, is that in an age when the models for political leadership and civic responsibility are put forth in American society for young people and others to learn from they are largely drawn from the ranks of a criminal, if not egregiously anti-democratic class, of elite financers and the rich. One example would be the highly revered Bill Gates. Chomsky offers a crucial, though often unacknowledged standard for how to be engaged with the world in ways in which issues of commitment and courage are tied to considerations of justice and struggle and not merely to the accumulation of capital regardless of the social costs. His decisive influence on a range of fields extending from linguistic theory to theories of the state and education have not only opened up new modes of inquiry but also give gravitas to the political impulse that underscores such contributions. The point here is neither to idolize nor demonize Chomsky — the two modalities that often mark reactions to his work. Rather the issue is to articulate the ways in which Chomsky as a public intellectual gives meaning to the dispositions and characteristics that need to be in place for such critical work: a historical consciousness, civic courage, sacrifice, incisiveness, thoughtfulness, rigor, compassion, political interventions, the willingness to be a moral witness, and the ability to listen to others.

As a public intellectual, Chomsky offers academics a way to be both scholars and critical citizens, and calls upon them to use their talents and resources to promote public values, defend the common good, and connect education to social change. He strongly rejects the notion that academics are merely servants of the state and that students are nothing more than enterprising consumers. The role of academics as public intellectuals has a long history in Chomsky's work and is inextricably connected to defending the university as a public good and democratic public sphere. Chomsky made this clear in a talk he gave at the Modern Language Association in 2000 when he insisted that

\footnotetext{
[u]niversities face a constant struggle to maintain their integrity, and their fundamental social role in a healthy society, in the face of external pressures. The problems are heightened with the expansion of private power in every domain, in the course of the state-corporate social engineering projects of the past several decades....To defend their integrity and proper commitments is an honorable and difficult task in itself, but our sights should be set higher than that. Particularly in the societies that are more privileged, many choices are available, including fundamental institutional change, if that is the right way to proceed, and surely including scholarship that contributes to and draws from the never-ending popular struggles for freedom and justice.[19]
}

Higher education is under attack not because it is failing, but because it is a potentially democratic public 
sphere. As such, conservatives and neoliberals often see it as a threatening institution that reminds them of the rebellious legacy of the sixties when universities were the center of struggles over free speech, anti-racist and feminist pedagogies, and the anti-war movement. Higher education has become a target for right-wing ideologues and the corporate elite because it is capable of teaching students how to think critically and it offers the promise of new modes of solidarity to students outside of the exchange value proffered by neoliberal instrumentalism and the reduction of education to forms of training. Chomsky extends the democratic legacy of higher education by insisting that universities and faculty should press the broader claims for economic and social justice.

He also argues more specifically that while higher education should be revered for its commitment to disinterested truth and reason, it also has a crucial role to play in its opposition to the permanent warfare state, the war on the poor, the squelching of dissent by the surveillance state, the increasing violence waged against students, and the rise of an authoritarian state engaged in targeted assassination, drone warfare, and the destruction of the environment. Part of that role is to create an informed and reflective democratic citizenry engaged in the struggle for social justice and equality. Chomsky has no interest in rooting the practice of freedom in the narrow discourses of identity politics with its particularized notion of freedom just as he has no interest in encouraging students to become apostles of fashionable intellectuals. This becomes clear when he writes about the need to go beyond fighting against the corporatization of the university. He stakes out a line of criticism that points to a general not a particular notion of freedom, refusing a politics and pedagogy largely defined within the parameters of a specialized academic discipline. For example, he writes:

The processes of corporatization are a serious threat to the liberatory and subversive function that the universities should try to serve in a free and healthy society. To defend their integrity and proper commitments is an honorable and difficult task in itself, but our sights should be set higher than that. Particularly in the societies that are more privileged, many choices are available, including fundamental institutional change, if that is the right way to proceed, and surely including scholarship that contributes to and draws from the never-ending popular struggles for freedom and justice.[20]

Standing for truth is only one role the university can assume, but it isn't enough. It must also fulfill its role of being attentive to the needs of young people by safeguarding their interests while educating them to exercise their capacities to fulfill their social, political, economic and ethical responsibilities to others, to broader publics, and the wider global social order. As Chomsky reminds us caring about other people is a dangerous idea in America today, and signals the transformation of the United States from a struggling democracy to a full-fledged authoritarian state.

[21] He writes:

If you care about other people, that's now a very dangerous idea. If you care about other people, you might try to organize to undermine power and authority. That's not going to happen if you care only about yourself. Maybe you can become rich, but you don't care whether other people's kids can go to school, or can afford food to eat, or things like that. In the United States, that's called "libertarian" for some wild reason. I mean, it's actually highly authoritarian, but that doctrine is extremely important for power systems as a way of atomizing and undermining the public.[22]

Given the intensive attack that is currently being waged against higher education, Chomsky's defense of the latter as a democratic public sphere and his insistence on the responsibility of intellectuals - be they academics, students, artists, educators, or cultural workers, to name only a few - takes on a new urgency. Public intellectuals can play a crucial political role in not only translating private issues into public concerns, but also offering up a discourse of interrogation and possibility, one that understands the new historical configuration in which we find ourselves when power is separated from politics, demanding not only a new consideration of politics and power but also what it means to think otherwise in order to act otherwise. Chomsky is an important public intellectual because he has become a model for what it means to put a premium on social and economic justice, display a willingness to raise disquieting questions, make power accountable, defend democratic values, take political risks, and exhibit the moral courage necessary to address important social issues as part of an ongoing public conversation.

This is not an easy task at a time when many academics have removed themselves from engaging larger social issues and are all too willing to accommodate those in power, functioning as either entertainers or stenographers. Too many academics have become either uncritical servants of corporate interests, rendered invisible, if not irrelevant, behind a firewall of professional jargon, or have been reduced to a subaltern class of adjunct and part-time labor, with little time to think critically or address larger social issues. Consequently, they either no longer feel the need to communicate with a broader public, address important social problems, or they are deprived of the conditions that enable them to write, think, and function as public and engaged intellectuals. This is particularly troubling in 
an aspiring democracy where intellectuals above all should take seriously the notion that if democracy is to mean anything it "requires its citizens to risk something, to test the limits of the acceptable."[23] This is particularly egregious when for many academics their working conditions no longer support their role as scholars and public intellectuals.

Noam Chomsky not only represents the antithesis of intellectual accommodation, he actually exemplifies a new kind of intellectual, one reminiscent of rigorous theorists such as Antonio Gramsci and Michelle Foucault, on the one hand, and C. Wright Mills, on the other, all of whom refused, as Mills put it, the role of "a sociological book-keeper," preferring instead to be "mutinous and utopian" rather than "go the way of the literary faddist and the technician of cultural chic."'24] Like C. Wright Mills, Chomsky addresses pressing social issues and painstakingly looks at how they are lived through the experiences of people who are often deeply affected, yet disappeared from such narratives. His work on political economy, regimes of authoritarianism, cultural domination, and global youth resistance is in my mind a pioneering work that examines the mechanisms of politics, and collective struggles globally within a larger matrix of economics, power, history, and culture. Chomsky is not content to focus on the perpetrators of global crime and the new forms of authoritarianism they are spreading in different ways across the globe, he also focuses on those who are now considered disposable, those who have been written out of the discourse of what he considers a tortured democracy, as a force for collective resistance capable of employing new modes of agency and struggle.

Whether he is talking about war, education, militarization, or the media, there is always a sense of commitment, civic courage, and a call for resistance in his work that is breathtaking and always moving. His interventions are always political and yet he manages to avoid the easy mantle of dogmatism or a kind of humiliating clownish performance we see among some alleged leftist intellectuals. Like C. Wright Mills, he has revived the sociological imagination, connecting the totality and the historically specific, a broader passion for the promise of democracy, and a complex rendering of the historical narratives of those who are often marginalized and excluded. There is also a refusal to shield the powerful from moral and political critique. Chomsky has become a signpost for an emerging generation of intellectuals who are not only willing to defend the institutions, public spheres, and formative cultures that make democracy possible but also address those anti-democratic forces working diligently to dismantle the conditions that make an aspiring democracy meaningful.

We live at a time when the growing catastrophes that face Americans and the rest of the globe are increasingly matched by the accumulation of power by the rich and financial elite. Their fear of democracy is now strengthened by the financial, political, and corporate elite's intensive efforts to normalize their own power and silence those who hold them accountable. For many, we live in a time of utter despair. But resistance is not only possible, it may be more necessary now than at any other time in America's past given the current dismantling of civil rights, democratic institutions, the war on women, labor unions, and the poor-all accompanied by the rise of a neoliberal regime that views democracy as an excess, if not dangerous and an obstacle to implementing its ideological and political goals. What Noam Chomsky has been telling us for over fifty years is that resistance demands a combination of hope, vision, courage, and a willingness to make power accountable, all the while connecting with the desires, aspirations, and dreams of those who suffer under the apparatuses of regimes of violence, misery, fear, and terror. He has also reminded us again and again through numerous historical examples that public memory contains the flashpoints for remembering that such struggles are always collective and not merely a matter of individual resistance. There are always gaps in the work we do as intellectuals, and in Chomsky's case there is more to be said as Archon Fung points out regarding the role that public intellectuals can play in shaping "the democratic character of public policy," work with "popular movements and organizations in their efforts to advance justice and democracy", and while refusing to succumb to reformist practices "join citizens—and sometimes governments—-to construct a world that is more just and democratic."'[25]

He may be one of the few public intellectuals left of an older generation that offers a rare glimpse into what it means to widen the scope of the meaning of political and intellectual inquiry —an intellectual who rethinks in a critical fashion the educative nature of politics within the changed and totalizing conditions of a neoliberal global assault on all vestiges of democracy. He not only trades in ideas that defy scholastic disciplines and intellectual boundaries, he also makes clear that it is crucial to hold ideas accountable for the practices they legitimate and produce while at the same time refusing to limit critical ideas to simply modes of critique. In this instance, ideas not only challenge the normalizing discourses and representations of commonsense and the power inequities they legitimate, but also open up the possibilities inherent in a discourse that moves beyond the given and points to new ways of thinking and acting about freedom, civic courage, social responsibility, and justice from the standpoint of radical democratic ideals. 


\section{Endnotes}

1. Gerry McCarthy, "The Social Edge Interview: Zygmunt Bauman." The Social Edge (February 2007), http://webzine.thesocialedge.com/interviews/thesocial-edge-interview-sociologist-and-author-zygmuntbauman/ (accessed January 6, 2013).

2. Wendy Brown, Regulating Aversion: Tolerance in the Age of Identity and Empire (Princeton, NJ: Princeton University Press, 2006), 16.

3. Irving Howe, “This Age of Conformity," Selected Writings 1950-1990, (New York: Harcourt Brace Jovanovich, 1990), pp. 29. 32.

4. Richard Sennett, Together : The Rituals, Pleasures and Politics of Cooperation (New Haven: Yale University Press, 2012), p. 30.

5. C. Wright Mills, The Politics of Truth: Selected Writings of C. Wright Mills, (New York: Oxford University Press, 2008), p. 200.

6. Chris Zuccotti, "Noam Chomsky: America Hates Its Poor", Reader Supported News (December 1, 2013). Online: http://readersupportednews.org/ opinion 2/277-75/20712-focus-noam-chomskyamerica-hates-its-poor

7. Frank B. Wilderson III, "Introduction: Unspeakable Ethics," Red, White, \& Black, (London, UK: Duke University Press, 2012), p. 2.

8. For a List of Chomsky's books, see: http://chomsky. info/books.htm

9. See, for example, Noam Chomsky, "The Responsibility of Intellectuals," New York Review of Books (February 13, 1967). Online: http://www.chomsky.info/ articles/19670223.htm. See also an updated version of this essay in Noam Chomsky, "The Responsibility of Intellectuals, Redux: Using Privilege to Challenge the State," The Boston Review (September 1, 2011). Online: https://www.bostonreview.net/noam-chomskyresponsibility-of-intellectuals-redux

10. Zygmunt Bauman, "Afterthought: On Writing; On Writing Sociology," Cultural Studies/Critical Methodologies 2:3 (2002), p. 364.

11. Terry Eagleton, “The Last Jewish Intellectual," New Statesman, March 29, 2004 http://www.newstatesman. com/node/147614; Edward Said's notion of travelling theory can be found in Edward W. Said, "Traveling Theory", in The Edward Said Reader, edited by Moustafa Bayoumi and Andrew Rubin (New York: Vintage, 2007), pp. 195-217.

12. Noam Chomsky, "Paths Taken, Tasks Ahead," Profession (2000), p. 32.
13. Ibid., Eagleton.

14. Stuart Hall and Les Back, "In Conversation: At Home and Not at Home", Cultural Studies, Vol. 23, No. 4, (July 2009), pp. 680-681.

15. Noam Chomsky, "An Ignorant Public Is the Real Kind of Security Our Govt. Is After," AlterNet (March 3, 2014). Online: http://www.alternet.org/chomskystaggering-differences-between-how-people-andpowerful-define-security

16. Ibid., Noam Chomsky, "An Ignorant Public Is the Real Kind of Security Our Govt. Is After."

17. See, for instance, the list of published debates in which he has engaged: http://chomsky.info/debates. htm

18. Over the course of his career, a number of false claims have been attributed to Chomsky, including the absurd notion published in the Times Higher Education Supplement that he was an apologist for the Pol Pot regime and on another occasion the damaging charge that he was anti-Semitic given his defense of freedom of speech, including that of the French historian Robert Faurisson, an alleged Holocaust denier. Chomsky's long standing critique of totalitarianism in all of its forms seems to have been forgotten in these cases. More recently a well-known left critic, capitalizing on his own need for indulging the performative, challenged Chomsky to a boxing match partly as a result of Chomsky's criticism of him. Granted this may be more ironic than literal, but in the end it reveals the collapse of serious dialogue into the dustbin of the heightened spectacle and a fatuous aesthetics. At issue in this instance is not an attempt at serious dialogue but a form of self-sabotage and a withdrawal from the serious engagement if not politics itself. Chomsky has never stooped to this level of selfimmolation or over-inflated grandiosity.

19. Noam Chomsky, "Paths Taken, Tasks Ahead," Profession (2000), p. 38.

20. Ibid., Chomsky, “Paths Taken, Tasks Ahead," p. 38.

22. See, for instance, Chris Zuccotti, "Noam Chomsky: America Hates Its Poor", Reader Supported News (December 1, 2013). Online: http:// readersupportednews.org/opinion2/277-75/20712focus-noam-chomsky-america-hates-its-poor

22. Ibid., Zuccotti, "Noam Chomsky: American Hates its Poor."

23. Mark Slouka, "Dehumanized: When Math and Science Rule the School," Harper's Magazine (September 2009), p. 38. 
24. C. Wright Mills, "Culture and Politics: The Fourth Epoch", The Politics of Truth: Selected Writings of C. Wright Mills, (Oxford University Press, 2008), p. 199

25. Archon Fung, "The Constructive Responsibility of Intellectuals," Boston Review, (September 9, 2011). Online: http://www.bostonreview.net/BR36.5/ archon_fung_noam_chomsky_responsibility_of_ intellectuals.php 
